\author{
MARÍA ELENA VEGA VILLALOBOS \\ PROGRAMA DE BECAS POSDOCTORALES EN LA \\ UNIVERSIDAD NACIONAL AUTÓNOMA DE MÉXICO \\ MÉXICO
}

\title{
El legado de los escultores: \\ un estudio de las firmas de artistas registradas \\ en los monumentos mayas del periodo Clásico Tardio
}

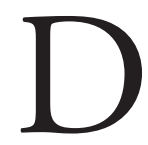

entro de la amplia gama de obra plástica que existe de los mayas del periodo Clásico (292-909) sobresale la realizada en piedra debido a la durabilidad de dicho material. Éste ha permitido una mejor conservación de los monumentos, recuperados entre los restos de los antiguos núcleos arquitectónicos. ${ }^{1}$ Esta obra conforma un variado corpus escultórico de estelas, dinteles, tableros, escaleras jeroglíficas y altares hechos con propósitos religiosos muy específicos, principalmente para la celebración de ciclos rituales de los gobernantes mayas, quienes se valieron de los monumentos públicos para transmitir diversas narrativas religiosas.

Debido a la colocación de los monumentos en lugares importantes y destacados, resulta evidente que el arte público se consideró un medio de encumbramiento social del que se valieron los gobernantes y grupos de elite para expresar su poder económico y político, el cual se conseguía —entre otras estrategias - mediante la ostentación de obras realizadas por artistas creativos, quienes elaboraban esculturas con innovaciones estéticas.

I. La gran cantidad de textos tallados en piedra con los que ahora se cuenta no implica, necesariamente, que fuera el material escriptorio preferido por los antiguos mayas, simplemente que es el mejor conservado. El medio húmedo ha generado una pobre conservación de textos escritos en otros tipos de material, principalmente orgánico, lo cual impide conocer el volumen de su producción en las antiguas ciudades, que quizá fue mayor a los realizados en piedra. 
Estos artistas, tallistas y escultores han salido del anonimato desde hace algunas décadas, cuando su firma se identificó en numerosas piezas cerámicas pintadas y en algunas estelas, dinteles, tableros y altares. ${ }^{2}$ En los monumentos públicos, las firmas se colocaron, generalmente, en lugares discretos pero muy visibles, y son etiquetas de identificación que permiten conocer a algunos de los innumerables artistas que trabajaron en las antiguas cortes mayas del Clásico Tardío (600-909).

En este artículo presento un estudio epigráfico de las firmas de los artistas más destacados que se conservan en algunos monumentos públicos para tratar de definir el papel real que el escultor desempeñó en la creación de una obra determinada, más allá del mensaje político y religioso que el comitente que la encargó quería transmitir. Es importante decir que en este artículo no examino el tema de las escuelas regionales de tallistas y escultores, el cual requiere un análisis más amplio que rebasa los objetivos de este ensayo.

\section{Los artistas mayas}

Los artistas que trabajaron en las antiguas cortes mayas comenzaron a firmar sus obras y a ser representados en vasijas cerámicas pintadas a partir del periodo Clásico Tardío, cuando una apertura social, aún no del todo comprendida, permitió que la escultura y la pintura dejaran de centrarse en la figura de los k'uhul ajawtaak, "señores sagrados" (gobernantes), y diera cabida a la aparición de actores políticos y religiosos secundarios de los señoríos, como reinas consortes, sacerdotes y jefes militares destacados. ${ }^{3}$ Esta apertura ha legado una serie importante de representaciones visuales de los antiguos escribas y artífices mayas. ${ }^{4}$

2. David S. Stuart, "An Early Maya Shell at Princeton", Record of the Princeton University Art Museum 48, núm. 2 (1989): 37-38; David S. Stuart, "A Study of Maya Inscriptions", tesis de doctorado (Nashville, Tennessee: Universidad de Vanderbilt, I995), 37I-372.

3. David S. Stuart, "Historical Inscriptions and the Maya Collapse", en Lowland Maya Civilization in the Eighth Century A.D. A Symposium at Dumbarton Oaks 7th and 8th, October I989, eds. Jeremy A. Sabloff y John S. Henderson (Washington D. C.: Dumbarton Oaks Research Library and Collection, 1993): 321-332.

4. Stephen D. Houston y Takeshi Inomata, The Classic Maya (Cambridge University Press, 2009), 258. 
Como se sabe por evidencia jeroglífica reciente, los artistas mayas también desempeñaron tareas políticas y ceremoniales al interior de los señoríos, ${ }^{5}$ pues algunos de ellos ostentaron el título de ajk'uhu'n, "venerador" o "adorador", 6 como el escultor del Dintel 4 de Bonampak. Ahora se sabe que este título lo utilizaron, según Marc U. Zender, ${ }^{7}$ para los sacerdotes que habitaban en la corte, poseedores de códices y quienes se encargaban de realizar rituales de invocación y propiciación de deidades. Además de ajk uhu’n, los artistas también presentan en sus cláusulas nominales los títulos de ajtz'ihb', "pintor" - literalmente "el de la pintura"-, itz'aat, "sabio" y miyaatz, "letrado".?

Las firmas de artistas se han identificado en textos jeroglíficos contenidos en piezas cerámicas pintadas, donde se encuentra la expresión $u t z$ ' $i b b^{\prime} a$, "lo pintó", seguida del nombre de quien había realizado la obra, como en el caso del vaso KI599: utz'ihb'a Ahkan Suutz', "Ahkan Suutz' lo pintó". Las firmas fueron un medio de encumbramiento social que dotó al artista, y a la misma pieza creada, de un estatus mayor, como ocurrió, por ejemplo, con las obras realizadas por el pintor Tub'al Ajaw. ${ }^{10}$

A su vez las firmas en cerámica revelan que algunos pintores formaron parte de la nobleza y la aristocracia mayas, pues en algunos casos, estas firmas incluyen los títulos y ascendencia del pintor, como ocurre en la vasija K635 elaborada

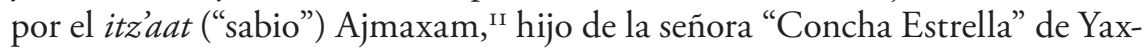
ha' y del gobernante K'ahk' Ukalaw Chan Chaahk, quien reinó en el señorío de Naranjo entre los años 755 y 780. La firma de Ajmaxam, colocada en el borde inferior de los jeroglíficos, resulta excepcional, pues es inusualmente larga, algo que evidencia la destacada identidad personal de Ajmaxam como artista y su notorio papel dentro de la producción artística de la corte de Naranjo.

5. Michael D. Coe y Justin Kerr, The Art of the Maya Scribe (Londres: Thames and Hudson, I997), 89-97.

6. Marc U. Zender, "A Study of Classic Maya Priesthood", tesis de doctorado (Universidad de Calgary, 2004), I80-194.

7. Stuart, "A Study of Classic Maya Priesthood", I80-194.

8. Stuart, "Historical Inscriptions and the Maya Collapse", 323.

9. Nikolai Grube, "Bajo los auspicios de Itzamnaaj: los escribas en los palacios reales", en Los mayas: voces de piedra, eds. Alejandra Martínez de Velasco y María Elena Vega (México: Editorial Ámbar Diseño, 20II), IO3.

Io. Erik Velásquez García, “Contexto histórico y cultural de los vasos de tradición 'Ik': el caso del pintor Tub'al 'Ajaw”, tesis de maestría (México: Universidad Nacional Autónoma de México-Facultad de Filosofía y Letras, 2007), 65-69.

II. Dorie Reents-Budet, Painting the Maya Universe: Royal Ceramics of the Classic Period (Londres: Duke University Press, 1994), 59-63. 


\section{Escultores y tallistas}

En 1986, David S. Stuart identificó la cláusula introductoria de la firma de escultores en algunos monumentos de piedra. ${ }^{.2}$ Dicha cláusula se construye, generalmente, con los fonogramas $y u, x u$ y $l u$, que forman la palabra yuxul, "su escultura", un sustantivo derivado del verbo transitivo uxul, "esgrafiar" o, más extensamente "esculpir, tallar". También se ha identificado el título anaab', "escultor" ${ }^{13}$ en algunos monumentos. ${ }^{\mathrm{I}}$

La única representación de un escultor maya que hay hasta el momento se encuentra en el Panel Emiliano Zapata (fig. I), elaborado a principios del siglo VIII. ${ }^{\text {I5 }}$ El escultor talla un monumento identificado como k'antuun, "piedra preciosa", término utilizado por los mayas para referirse a las esculturas labradas en piedra. Para la talla utiliza lo que parece ser una herramienta fabricada a partir de colmillos o garras de pecarí. ${ }^{16}$ Los jeroglíficos ubicados por encima de la mano del artista hablan de la creación de la obra, pues señalan que "la espalda de la piedra preciosa [escultura] 7 Ajaw entonces fue esculpida".

Tenemos otros monumentos que denotan al escultor de una obra en piedra. Esta identificación se da no mediante una firma, sino por medio de la expresión chehe’n, "así dice”, como en el Tablero 9 de Ceibal, último panel jeroglífico de una serie de nueve tableros colocados en los escalones de la Estructura A-I4 erigidos en el año 75I. ${ }^{17} \mathrm{Al}$ final del texto (donde se narran una serie de acontecimientos políticos y rituales protagonizados por los gobernantes de Ceibal y Dos Pilas) se lee chehe'n ti yuxul Na'm Ajpulu'm: "así dice en la escultura de Na'm, el de Pulu'm".

I2. Stuart, "An Early Maya Shell at Princeton”, 37-38. Véase Carolyn Tate, “Ah Ts'ib: Scribal Hands and Sculpture Workshops at Yaxchilán”, en Seventh Palenque Round Table, I989 (San Francisco, California: The Pre-Columbian Art Research Institute, 1994), 95-96.

I3. Albert Davletshin, comunicación personal, 2014.

I4. Como en la Piedra Labrada 5 de Bonampak, figura 2 de este artículo; la estela de procedencia desconocida que presento en la figura 6, el Dintel 46 de Yaxchilán, entre otros.

15. Mercedes de la Garza, Guillermo Bernal Romero y Martha Cuevas García, PalenqueLakamha'. Una presencia inmortal del pasado indigena (México: Fondo de Cultura EconómicaEl Colegio de México, 2012): I84.

I6. Houston e Inomata, The Classic Maya, 267.

I7. 9.16.o.o.o, 2 Ajaw I3 Kase'w, 5 de mayo de 75I. María Elena Vega Villalobos, "La historia de Ceibal en la época clásica", tesis de maestría (México: Universidad Nacional Autónoma de México-Facultad de Filosofía y Letras, 2009), I49-I52. 


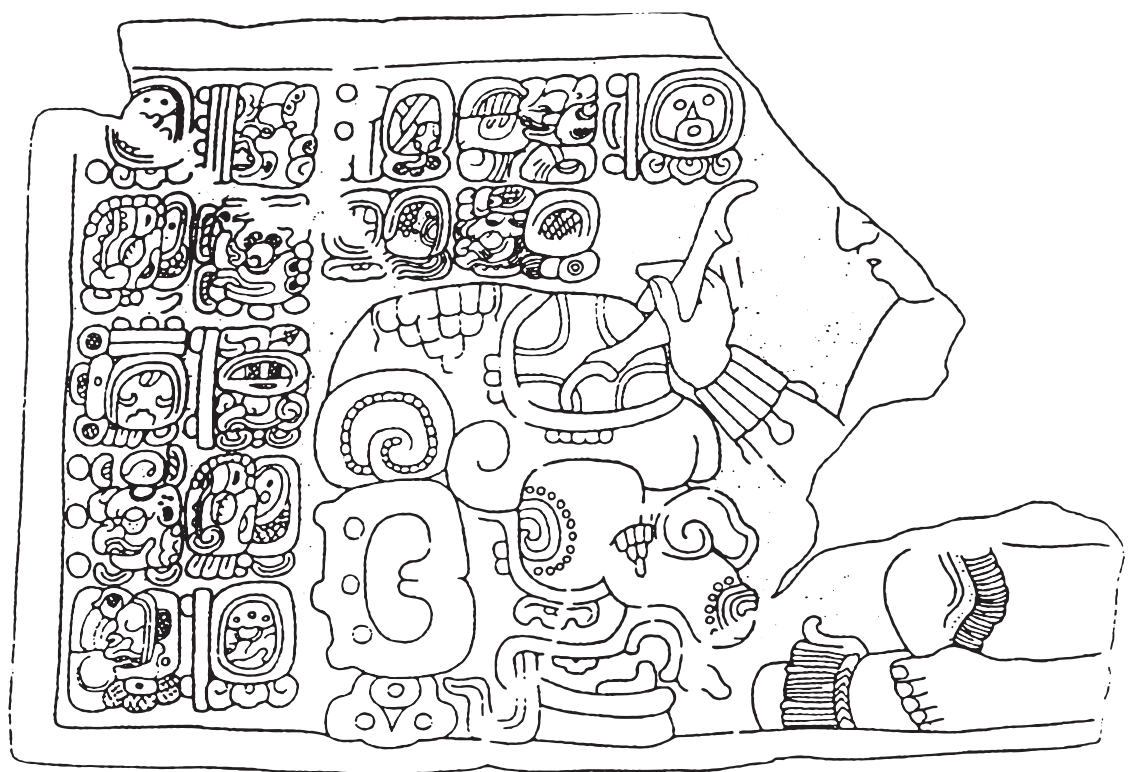

I. Panel Emiliano Zapata que representa a un escultor maya del periodo Clásico tallando un monumento denominado k'antuun, "piedra preciosa". Dibujo: Linda Schele. The Linda Schele Drawings Collection, 2000 (C) David Schele. www.famsi.org/research/schele/

Otra referencia interesante a un escultor se encuentra en la Piedra Labrada 5 de Bonampak (fig. 2), una escultura tallada entre los años 642 y $648 .{ }^{18}$ Este monumento presenta una larga inscripción jeroglífica que forma dos textos independientes, característica señalada por los tallistas por medio de la diferencia de tamaño entre la columna inicial (que comienza en la parte superior izquierda) y la secundaria, colocada a la izquierda debajo de los jeroglíficos más grandes y que continúa hasta el texto inscrito bajo el personaje principal, sentado en un trono a la derecha de la imagen. Esta inscripción secundaria señala que tanto el escultor y ch'aho'm, como el señor de Usiij Witz [Bonampak] ${ }^{19}$

I8. Péter Bíró, "Las piedras labradas 2, 4 y 5 de Bonampak y los reyes de Xukalnah en el siglo VII", Estudios de Cultura Maya, núm. XXIX (2007): 53.

19. Dmitri Beliaev y Alexander Safronov, "Saktz'i', 'Ak'e' and Xukalnaah: Reinterpreting the Political Geography of the Upper Usumacinta Region”, I4th European Maya Conference (I3 y I4 de noviembre, 2009). Disponible en: https://www.academia.edu/7982378/Saktz_i_ Ak_e_and_Xukalnaah_Reinterpreting_the_Political_Geography_of_the_Upper_ Usumasinta_Region_with_Alexander_Safronov_ 
fueron llamados a la presencia de Yaxuun B’ahlam, gobernante de Yaxchilán. El hecho de que el escultor - en esta inscripción denominado anaab' - ostente el título de ch'aho'm, un título común de los gobernantes mayas y otros personajes destacados de los señoríos, señala que algunos escultores y tallistas (muy probablemente los maestros escultores) ocuparon un lugar prominente dentro del estamento social del periodo Clásico Tardío.

\section{Las firmas registradas en monumentos}

Como señalé anteriormente, la escultura pública entre los mayas prehispánicos se utilizó como el medio por excelencia para expresar el poder religioso y político del gobernante, pero también para afirmar su poderío social y económico. Este afán ha legado monumentos excepcionales que presentan innovaciones artísticas que no rompieron con los cánones religiosos y políticos firmemente establecidos, algo posible de constatar en los textos jeroglíficos registrados, los cuales señalan que las esculturas no dejaron de verse como vehículos narrativos de temas religiosos. Las innovaciones se restringieron a la imagen representada en el monumento, donde algunos escultores y tallistas pudieron plasmar su capacidad de creación personal de formas.

Una de las firmas más tempranas que existen en una escultura pública procede del núcleo arquitectónico de Arroyo de Piedra, un señorío ubicado en la región Petexbatún, Guatemala. La firma se talló en el frente de la Estela I, un monumento creado para conmemorar la fecha de finales del periodo 9.9.0.0.0, 3 Ajaw 3 Zotz', 9 de mayo de 613. ${ }^{20}$ A pesar de que el corpus escultórico de Arroyo de Piedra es muy limitado y casi todas las estelas tempranas se encuentran fragmentadas, se puede decir que la Estela i presentó por primera vez, en esa región, a un gobernante de Tamarindito/Arroyo de Piedra como la personificación de una deidad, en este caso el dios Remero Espina de Raya. ${ }^{21}$ Otra innovación estética en la región Petexbatún, evidente en este monumento, se encuentra en la parte inferior de la escultura, donde se representa el topóni-

20. María Elena Vega Villalobos, "La entidad política de Dos Pilas: un señorío maya del periodo Clásico", tesis de doctorado (México: Universidad Nacional Autónoma de MéxicoFacultad de Filosofía y Letras, 20I4), 70-73.

2I. Por supuesto, la personificación de deidades y la representación plástica de ellas existen desde el periodo Preclásico. Aquí me refiero a que es el primer ejemplo de esto en una escultura realizada en la región Petexbatún. 


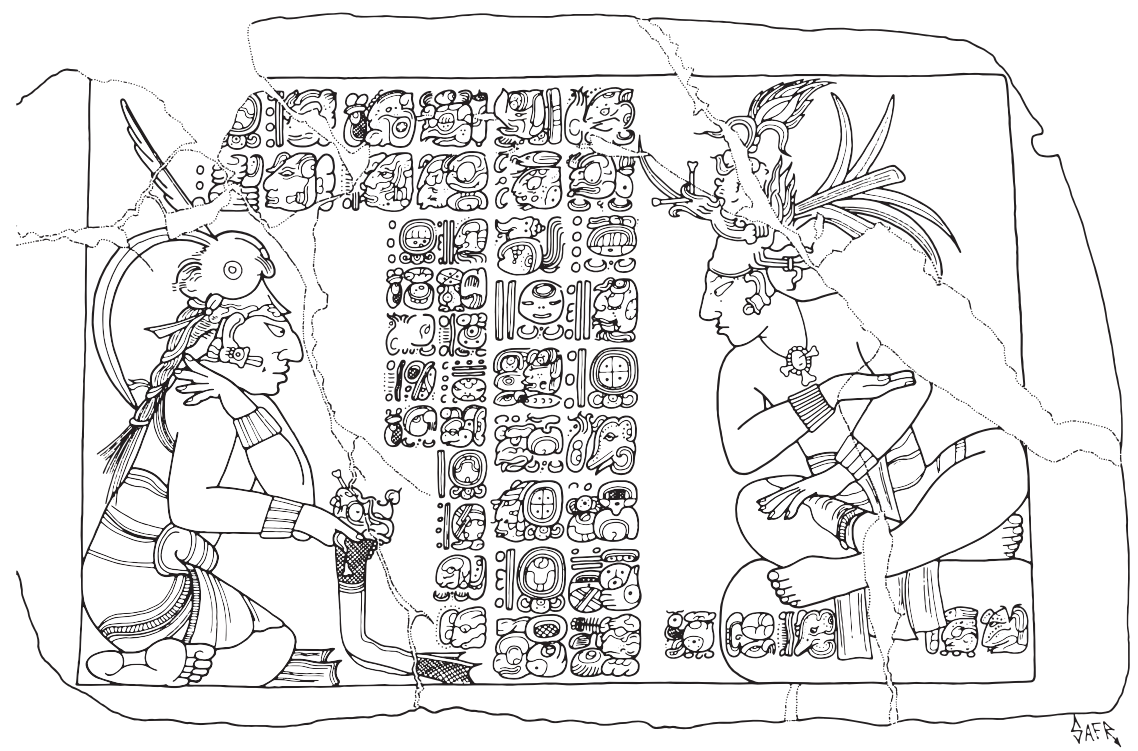

2. Piedra Labrada 5 de Bonampak. El texto jeroglífico colocado en el trono a la derecha de la imagen nombra al escultor. Tomado de Wayeb Drawing Archive, (C) Alexandre Safronov. http://www.wayeb.org/drawings/bpk_msc_05.png

mo de la entidad política de Tamarindito, una convención artística que con el tiempo se volvió común en todas las estelas creadas por los gobernantes de los distintos señoríos del Petexbatún. La firma de la Estela I, conformada por nueve cartuchos jeroglíficos, señala que "es la escultura del joven Chijwitz, Ixiim Peet Ajaw, [...] así se dice".

Contemporáneo a esta escultura es el monumento denominado Piedra Labrada 4 de Bonampak (fig. 3). Aunque el texto jeroglífico sólo registra fechas a partir de ruedas del calendario, por el estilo caligráfico se ha ubicado entre 600 y $614 .{ }^{22}$ Se encontró en la escalinata principal del Edificio 8 y se cree que originalmente estuvo adosada a una de las paredes de dicha estructura, a manera de panel o tablero. El texto jeroglífico ocupa casi toda la superficie de la escultura, la cual enmarca a dos personajes: el de la izquierda identificado como Yajaw Chan Muwaan, gobernante del señorío de Xukalnaah, en la

22. Beliaev y Safronov, 'Saktz'i', 'Ak'e' and Xukalnaah: Reinterpreting the Political Geography of the Upper Usumacinta Region”; Bíró, "Las piedras labradas 2, 4 y 5 de Bonampak y los reyes de Xukalnah en el siglo viI", 35 . 


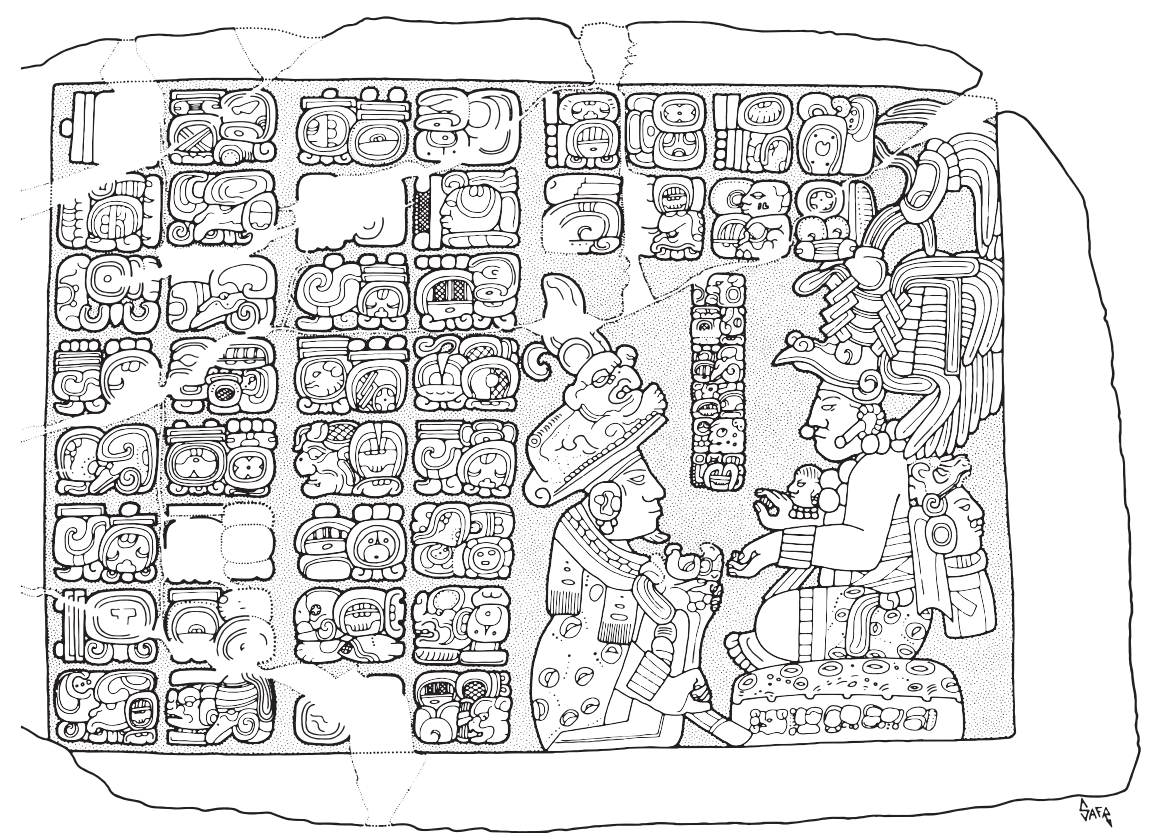

3. Piedra Labrada 4 de Bonampak. El texto jeroglífico, ubicado en el trono del gobernante, es la firma del escultor. Tomado de Wayeb Drawing Archive, (C) Alexandre Safronov. http://www. wayeb.org/drawings/bpk_msc_04.png

región del Usumacinta. Éste se encuentra arrodillado frente a un señor más poderoso sentado en un trono de piel de jaguar: el gobernante Itzamnaah Kokaaj B’ahlam de Yaxchilán. Aunque la conservación del panel en general es muy buena, no ocurre lo mismo con el pequeño texto jeroglífico, colocado en la parte inferior del trono de Itzamnaah Kokaaj B'ahlam, donde se registró la firma del escultor del panel, de la cual únicamente se lee la expresión introductoria yuxul, "su escultura". El nombre del escultor, quizá sus títulos y procedencia, no se han conservado.

Más de medio siglo después, en el señorío de Piedras Negras, Guatemala, se vuelven a encontrar firmas de artistas en un monumento público. ${ }^{23}$ Se regis-

23. Numerosos monumentos de Piedras Negras presentan firmas de artistas, como el Altar 4, y las estelas I2, I3, I4 y I5. Analizaré algunas de estas esculturas más adelante, pues el orden de exposición sigue un patrón cronológico, el cual permitirá ver los cambios en las firmas a lo largo del periodo Clásico Tardío. 
traron en la Estela 6, realizada durante el reinado de K'ihnich Yo'nal Ahk II $(687-729) .{ }^{24}$ Esta escultura (fig. 4), erigida el in de abril de $687,{ }^{25}$ es la primera de muchas estelas-nicho creadas en Piedras Negras, una innovación artística en los monumentos del sitio que con el tiempo se volvió muy popular entre los artesanos de Piedras Negras. En el frente de la estela encontramos siete firmas distintas. Para Nikolai Grube, la ubicación de las firmas de los escultores no es casual, pues señalan la parte del monumento que fue creado por el artista que firma esa sección. Aunque esta propuesta es interesante, no se cuenta con otros datos que la confirmen. ${ }^{26}$ No obstante, las siete firmas que presenta la Estela 6 evidencian que varios escultores trabajaron de forma conjunta en la creación de esculturas públicas. Los nombres de los tallistas son Suutz', Ajho'tuun Joy B'ahlam, Chanal Le'm, K'awiil, Sakpaach K'uk' Uhxb'aah, Sak B'ahlam y uno no identificado.

Muy cerca de la ciudad de Piedras Negras se encuentra el señorío de Yaxchilán, un sitio ubicado en el margen izquierdo del río Usumacinta. Desde finales del siglo vir Itzamnaah Kokaaj B’ahlam II gobernó la ciudad. Durante su reinado — que duró más de 60 años según los documentos del sitio— se erigieron numerosas estructuras en la zona central de Yaxchilán y se realizaron varios monumentos públicos, ${ }^{27}$ los cuales inauguraron una imaginería muy particular en la narrativa visual de este gobernante. El corpus escultórico de Yaxchilán presenta una gran cantidad de dinteles de piedra labrados que se adosaron a diversas estructuras, una práctica que se remonta a los primeros gobernantes del sitio. Sin embargo, antes de la entronización de Itzamnaah Kokaaj B’ahlam II (en el año 68I), los dinteles presentan únicamente textos jeroglíficos que relatan diversos acontecimientos políticos y religiosos de los mandatarios. Como se verá, los escultores que trabajaron para Itzamnaah Kokaaj B’ahlam II introdujeron innovaciones artísticas que produjeron monumentos excepcionales en Yaxchilán y en toda la zona maya del periodo Clásico.

Los primeros monumentos esculpidos durante el reinado de Itzamnaah Kokaaj B'ahlam II se realizaron en lajas de piedra colocadas como dinteles

24. Péter Bíró, "La organización política maya clásica (200-900): la ciudad de Piedras Negras", tesis de maestría (México: Universidad Nacional Autónoma de México-Facultad de Filosofía y Letras, 2004), 65-66.

25. 9.I2.I5.0.0, 2 Ajaw 3 Zip.

26. Nikolai Grube, comunicación personal, 201 .

27. María Elena Vega Villalobos, "La Casa del Cielo. Yaxchilán en la época de Escudo Jaguar II: 68I-723 d. C.”, tesis de licenciatura (México: Universidad Nacional Autónoma de México-Facultad de Filosofía y Letras, 2006), 39-65. 


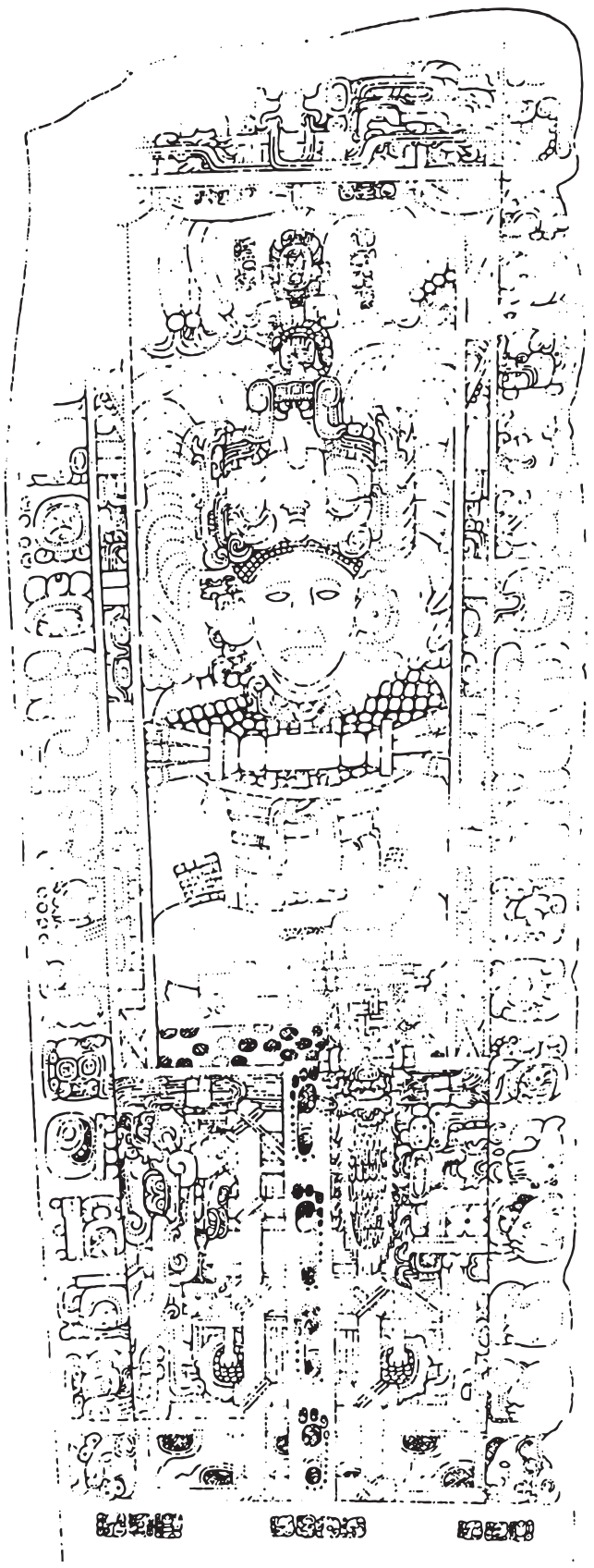

4. a) Frente de la Estela 6 de Piedras Negras, la primera estela-nicho creada en el sitio. Tomada de The John Montgomery Drawings Collection, D.R. (C) 2000 John Montgomery. http://research.famsi.org/uploads/ montgomery/hires/jmo5267pnsto6fr.jpg 
a)

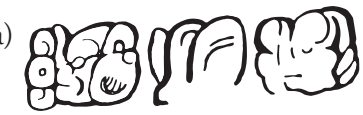

b)

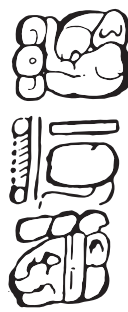

d)

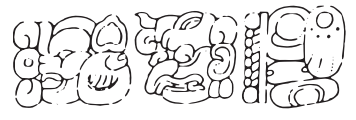

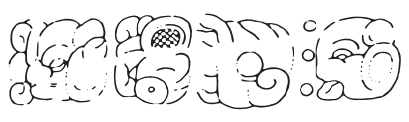

f)

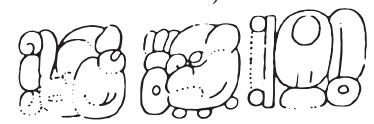

4b) Aquí se presentan las firmas de artistas que se registraron en el monumento; a) CI-EI: Suutz; b) Ir-I3: Ajho'tuun Joy B'ahlam; c) JI-J4: Chanal Le'm: d) KI-MI=: K'awiil; e) NI-QI:

Sakpaach K'uk Uhxb'aah; f) Ri-Tr: Sak B'ahlam. Tomados de The John Montgomery Drawings Collection, D.R. (c) 2000 John Montgomery, JMo5260-JMo5266.

en los tres vanos de acceso de la Estructura 44, y corresponden a los dinteles 44, 45 y 46. Estas esculturas tienen imágenes de Itzamnaah Kokaaj B’ahlam II sometiendo a diversos cautivos. Dos de estos dinteles, el 45 y el 46, presentan firma de artistas. En el Dintel 45, que lleva la fecha 22 de febrero de 68I, está escrito "es la escultura de Ju'nwitzil Chaahk, el joven Chakjalte". Mientras que en el 46, fechado el I4 de noviembre de 7I3, dice "es la escultura de Tz'ihb'aal Chaahk. [Él es] el escultor del ch'aho'm [del dios] Chaahk, señor sagrado de Pa'chan [Itzamnaah Kokaaj B'ahlam II], la cabeza de la tierra”. Para Carolyn Tate, este escultor también participó en la creación de la Estela I2 de Yaxchilán, ${ }^{28}$ un monumento que no cuenta con firma de artista.

Algunos años después, los escultores y arquitectos de Itzamnaah Kokaaj B'ahlam II emprendieron la construcción y decoración de la Estructura 23, un edificio identificado como la casa de la señora K’ab’al Xook, esposa principal del gobernante, que también sirvió como mausoleo para ambos

28. Tate, "Ah Ts'ib: Scribal Hands and Sculpture Workshops at Yaxchilán", 97. 
personajes. ${ }^{29}$ Cuatro de los cinco vanos de acceso de la estructura presentan dinteles de piedra labrados. Los que se colocaron en las entradas que miran a la Plaza Principal presentan breves textos jeroglíficos e imágenes excepcionales de la realeza de Yaxchilán, considerados obras maestras de la civilización maya.

Los dinteles 24, 25 y 26, creados alrededor del año 725 , se diseñaron para que la inscripción en el canto formara parte de la fachada del edificio, mientras que el frente sólo podía apreciarse al entrar en los cuartos de la estructura. Estos tres dinteles tienen una secuencia visual ${ }^{30}$ que ilustra tres rituales donde participan Itzamnaah Kokaaj B’ahlam II y la señora K’ab’al Xook, pero sólo el 24 y 26 tienen firma de artista.

En el Dintel 24 la firma del escultor está colocada discretamente y en bajorrelieve en la parte inferior izquierda de la imagen: "la escultura de Aj Chaahkil Anal se levantó". En el Dintel 26, la firma del artista presenta una frase completa de dedicación del monumento, pues se inicia con una fecha en rueda de calendario y le sigue el verbo t'ab', "ascender, levantarse", común de las fórmulas dedicatorias de piezas cerámicas. ${ }^{3 \mathrm{I}}$ Así, la firma se leería de la siguiente forma: "el 8 de febrero de 724, la escultura de K'awiil Chaahk Ajsak Ook se levantó". Dato que señala que el escultor fue extranjero, y evidencia que el poderío de Yaxchilán durante el reinado de Itzamnaah Kokaaj B’ahlam II se extendió por una gran parte de la región del Usumacinta.

Estos dinteles (44, 45, 46, 24, 25 y 26) desarrollaron la idea narrativa en las puertas de las estructuras 44 y 23 de varios eventos bélicos, políticos y religiosos de la pareja real de Yaxchilán. Su calidad artística e innovación estética — pues los dinteles de Yaxchilán anteriores a Itzamnaah Kokaaj B’ahlam II no presentan imágenes - crearon un patrón de fórmulas que sucesivos tallistas del señorío imitaron, quienes, a pesar de poseer técnicas escultóricas muy destacadas, no pudieron igualar la calidad de los escultores que trabajaron para Itzamnaah Kokaaj B’ahlam II.32

29. Roberto García Moll, "Shield Jaguar and Structure 23 at Yaxchilan", en Courtly Art of the Ancient Maya, eds. Mary Miller y Simon Martin (San Francisco: Thames \& Hudson, 2004), 268-270.

30. Miller y Martin, Courtly Art of the Ancient Maya, ro6.

31. David S. Stuart, "Glyphs on Pots. Decoding Classic Maya Ceramics”, en Sourcebook for the 29th Maya Hieroglyphic Forum (The University of Texas at Austin-Department of Art and Art History-Maya Workshop Foundation, 2005), IIO-197.

32. Miller y Martin, Courtly Art of the Ancient Maya, 108. 
Algunos ańos después de que se realizaran los dinteles del Edificio 23 de Yaxchilán, en la gran urbe de Calakmul, Campeche, el gobernante Yuhkno'm Took' K'awiil (702-73I ${ }^{33}$ ordenó la creación de dos monumentos excepcionales: las estelas I y 5r. La primera con la figura de una de las esposas de Yuhkno'm Took' K'awiil junto a un enano que se desempeńó como ayudante ritual. La mala conservación de la piedra en que se talló esta escultura ha ocasionado que algunas de las firmas de artistas se hayan perdido. Sin embargo, se pueden identificar con seguridad ocho rúbricas de escultores colocadas en diversos lugares, como en el escudo rodela que sostiene la reina consorte en la mano izquierda.

Por otro lado, la Estela 51, que conmemora la fecha de final de periodo 9.I5.0.0.o (año 73I), se elaboró en una piedra no tan porosa como las usadas comúnmente en Calakmul, lo cual ha permitido una conservación excelente de la imagen y los textos jeroglíficos. La escultura muestra la representación del gobernante Yuhkno'm Took' K'awiil; los jeroglíficos tallados en altorrelieve refieren la fecha, nombre y títulos del gobernante, mientras que los signos tallados en bajorrelieve, colocados frente al rostro del mandatario, señalan el nombre de los dos escultores de la estela. Uno de ellos es Sak Ikin, ${ }^{34}$ un tallista que llevó el título k’uhul chatahn winik, "persona sagrada de Chatahn". Los artistas que ostentaron este título fueron, durante este periodo, los mejores escultores y pintores, y muy posiblemente súbditos de los señores del Reino de la Serpiente durante el siglo viII. ${ }^{35}$ Esto podría explicar por qué el gobernante Yuhkno'm Took' K'awiil comisionó a Sak Ikin para realizar la Estela 5I, una escultura que constituye una innovación artística en el tallado en altorrelieve sin precedentes en Calakmul, un monumento excepcional y sin duda alguna uno de los más bellos conservados de este señorío.

Una escultura de procedencia desconocida, creada probablemente en las primeras décadas del siglo viII, cuenta con dos firmas de artistas. La estela muestra la imagen de la señora Ook Ahiin de un sitio identificado como

33. Simon Martin y Nikolai Grube, Crónica de los reyes y reinas mayas. La primera historia de las dinastias mayas, trad. Lorenzo Ochoa (México: Fondo de Cultura Económica, 2002), II2.

34. David Stuart, Simon Martin y Marc Zender, "Sculptors and Subjects: Notes on the Incised Text of Calakmul Stela 5I", en Maya Decipherment. Ideas on Ancient Maya Writing and Iconography (7 de enero de 20I5). Disponible en: https://decipherment.wordpress. com/20I5/or/o7/sculptors-and-subjects-notes-on-the-incised-text-of-calakmul-stela-5I/

35. Carlos Pallán Gayol, Breve historia de los mayas (Madrid: Nowtilus, 2011), 294-295. 
Yomop; los jeroglíficos tallados frente a su rostro, en altorrelieve, proporcionan su nombre y títulos. Los dos largos textos jeroglíficos realizados en bajorrelieve, colocados en las orillas de la estela, corresponden a dos firmas de escultores. La inscripción de la izquierda señala que "es la escultura de 4 Ajaw, el de Uhxte' K'uh, el escultor de la señora Ook Ahiin, señora cabeza de la tierra”. Para algunos investigadores, este escultor, llamado 4 Ajaw, está representado en el tablero sur del Templo XIX de Palenque. ${ }^{36}$ La firma del lado derecho señala el nombre de otro tallista, quien es "el escultor de Ajyul K'inich Winikhaab', el venerador/adorador, el artista”. A pesar de lo largas que son estas firmas, la parte que menciona a los escultores es muy breve, y sólo se limita a señalar su nombre y a decir que son los escultores (yanaab'il) de personajes importantes: de la señora Ook Ahiin y de un sacerdote (ajk'uh'n) y sabio (itz'aat) destacado, llamado Ajyul K'inich Winikhaab'.

Durante la segunda mitad del siglo viII se encuentran en Piedras Negras varias esculturas firmadas. La Estela I4, un monumento realizado para celebrar la fecha 9.I6.Io.o.o (año 76I), presenta al gobernante Yo'nal Ahk III de frente y sentado en un trono. La estela se ejecutó en el estilo nicho inaugurado en el siglo viı, con los escultores que tallaron la Estela 6 en el año 687. Las firmas, seis en total, se ubican al frente del monumento (fig. 5). Entre ellas hay una colocada en el trono del gobernante, en una posición superior respecto a las otras que podría indicar un estatus mayor. La firma corresponde a un escultor llamado Koto'l Tz'ihb' Pol, quien también trabajó en las esculturas del sucesor de Yo'nal Ahk III, y ostentó el título de escultor pol, el cual puede traducirse como "cortador de piedras". ${ }^{37}$

La Estela I4 añade una innovación artística en el canon de representación, pues no sólo aparece el gobernante Yo’nal Ahk III, sino también una mujer, la reina consorte, en un primer plano, de pie, con el cuerpo de perfil y el rostro elevado mirando al mandatario. A pesar de que ambos personajes no se superponen en la escena, la figura de la mujer es más llamativa en la escultura, como si quisiera señalarse que ella es la verdadera protagonista del monumento.

Diez años después, en 77I, el sucesor de Yo'nal Ahk III, el gobernante Ha'k'in Xook, mandó erigir la Estela I3 (fig. 6) para celebrar la fecha de final

36. David S. Stuart, The Inscriptions from Temple XIX at Palenque. A Commentary (San Francisco: The Pre-Columbian Art Research Institute, 2005), II5-II7; De la Garza, Bernal Romero y Cuevas García, Palenque-Lakamha'. Una presencia inmortal del pasado indigena, 224. 37. Martin y Grube, Crónica de los reyes y reinas mayas, I53. 
5. Frente de la Estela I4 que presenta seis firmas de artistas. Tomada de The John Montgomery Drawings Collection. D.R. (C) 2000 John Montgomery.

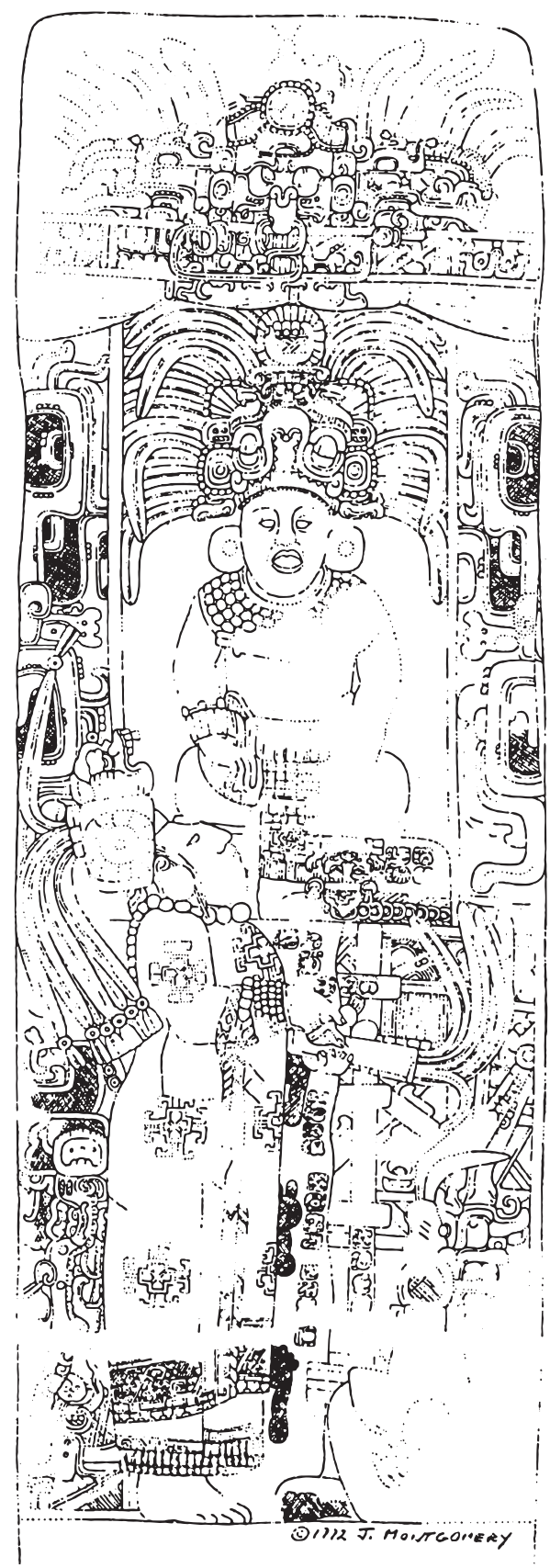




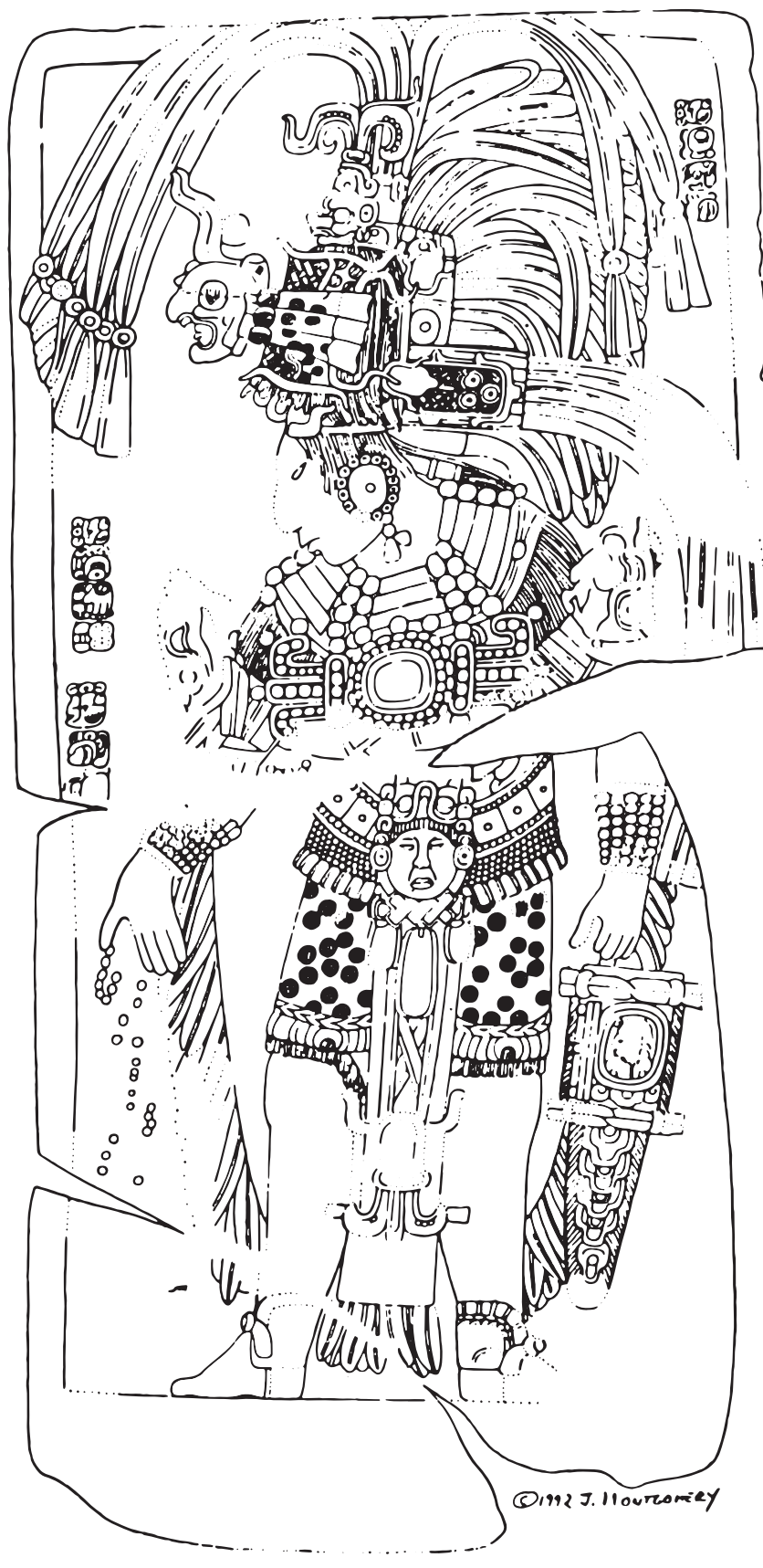

6. Frente de la Estela I3 con las tres firmas de los escultores. Tomada de The John Montgomery Drawings Collection, D. R. (C) 2000 John Montgomery. http://research. famsi.org/uploads/ montgomery/hires/ jmo5363pnstizfr.jpg 
del periodo 9.17.0.0.0. Al frente de la estela, donde se ve la representación de Ha'k'in Xook, aparecen tres firmas, entre ellas está nuevamente la de Koto'l Tz' ihb' Pol, escultor y cortador de piedras del anterior gobernante que trabajó en la Estela I4, y Yajaw Kalo'mte', tallista que también esculpió para el Gobernante 7. La Estela I3 es un monumento atípico en Piedras Negras, no sólo por la colocación de las firmas de los escultores, sino también por la imagen del gobernante quien, representado de pie, con el cuerpo de frente y el rostro de perfil, realiza el rito de tirar incienso (choko'w ch'aaj) y sostiene con la mano izquierda una bolsa de copal con la fecha I3 Ajaw. Aunque este tipo de imagen del gobernante es muy común en la escultura pública maya del periodo Clásico Tardío, es casi un ejemplo único en Piedras Negras, que no se repite durante los reinados de los sucesores de Ha'k'in Xook.

De vuelta al señorío de Bonampak, que presenta esculturas con firmas de artistas desde principios del siglo viI. Durante la segunda mitad del siglo viII, con el reinado de Yajaw Chan Muwaan II, Bonampak vive un resurgimiento político muy ligado a Yaxchilán. Este sitio, a pesar de no contar con firmas de escultores en sus monumentos desde la muerte de Itzamnaah Kokaaj B'ahlam II, seguía manteniendo un estamento de escultores y artífices destacados. A este cuerpo se le envió a Bonampak para realizar estelas y dinteles que representan a los gobernantes de ambos señoríos - como los dinteles de piedra i y 2 adosados en los vanos de acceso del Edificio I, los cuales muestran a los mandatarios en escenas de sometimiento y captura de prisioneros, un estilo muy particular de Yaxchilán que se inició con los escultores de Itzamnaah Kokaaj B’ahlam II. Aunque los nombres y títulos de los tallistas de estos dinteles no son legibles en la actualidad, es de suponer que pertenecían a Yaxchilán tanto por el estilo como por la firma que sí se conserva en la Estela i de Bonampak. Ahí se señala que la estela es de la autoría del escultor ( yanaab'il) del señor sagrado de Pa'chan, es decir, el escultor del gobernante Chelte' Chan K’inich de Yaxchilán.

Otro monumento con firma y que muestra al gobernante Chelte' Chan K'inich es el Dintel I de Laxtunich (fig. 7), con fecha 22 de agosto de 783. Se trata de una escena palaciega (poco común en monumentos de piedra) y una interesante alteración en el orden tradicional de representación, pues el personaje principal, el gobernante de Yaxchilán, se encuentra sentado en un trono a la izquierda de la imagen y no a la derecha. En la parte superior del dintel se aprecian las cortinas enrolladas propias de espacios interiores. El personaje colocado a la derecha — posición privilegiada dentro de los cánones estéticos mayas - se identifica en el texto central (ubicado frente al rostro del gobernan- 


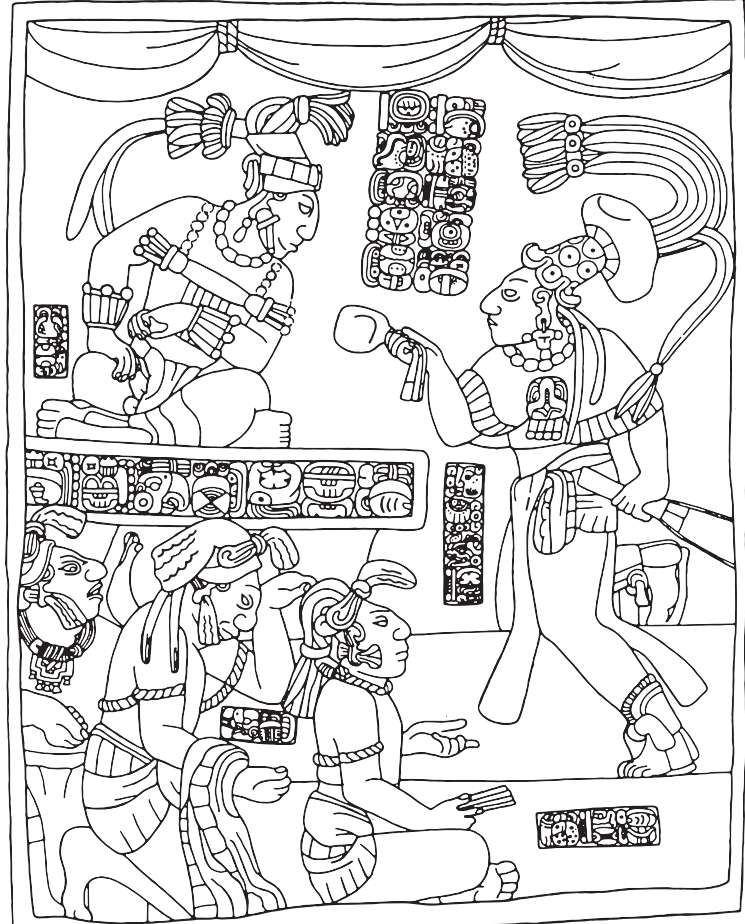

7. Panel de Laxtunich. La firma del escultor de Piedras Negras se ubica debajo del brazo derecho de Ajchak Maax. Tomado de The John Montgomery Drawings Collection, D.R. (C) 2000 John Montgomery. http:// research.famsi.org/uploads/ montgomery/638/image/ jmoI220.jpg

te) como Ajchak Maax. Éste le entrega a Chelte' Chan K'inich tres prisioneros de guerra identificados con pequeñas cláusulas jeroglíficas. Debajo del brazo derecho de Ajchak Maax está, tallada en bajorrelieve, la firma del artista: "es la escultura de Mayuy Ti'..., el de K'ihna”, es decir, el tallista Mayuy estuvo relacionado de alguna manera con el señorío de Piedras Negras, pues K'ihna' es un nombre asociado - de forma que aún no queda clara- a este sitio. La escena palaciega del dintel de Laxtunich, aunque es poco común en esculturas públicas mayas, es parte de una tradición artística de los escultores de Piedras Negras, quienes crearon ejemplos destacados de este tipo de escenas en monumentos de piedra, como la que vemos en el Tablero 3, del año 749.

Algunas décadas antes de que la ciudad de Piedras Negras colapsara, el Gobernante 7 , que inició su reinado en el año $78 \mathrm{I},{ }^{38}$ comisionó la creación de dos esculturas excepcionales: las estelas i2 y I5. La Estela is (fig. 8), erigida en

38. Martin y Grube, Crónica de los reyes y reinas mayas, $\mathrm{I} 52$. 
8. Frente de la Estela Is de Piedras Negras. Las firmas de los escultores se ubican a la derecha de la imagen. Tomada de The John Montgomery Drawings Collection,

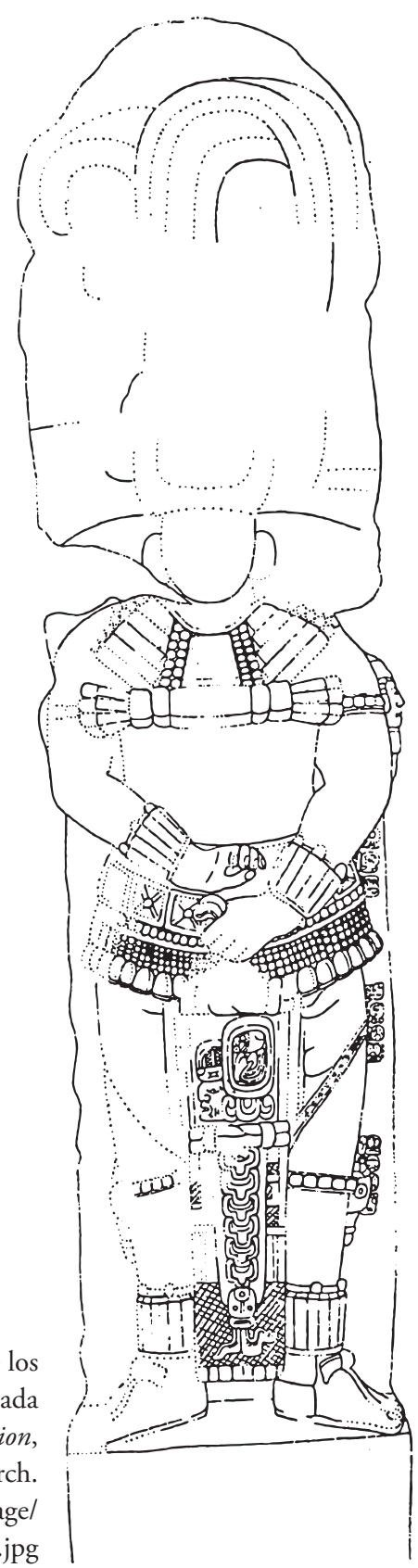

D.R. (C) 2000 John Montgomery. http://research. famsi.org/uploads/montgomery/525/image/ jmo5385.jpg 
el año 785, es el primer monumento del Gobernante 7. Realizado en piedra caliza, muestra la representación de cuerpo completo del personaje en una técnica tridimensional. En el frente de la estela se ve al mandatario de pie, sosteniendo en la mano izquierda una bolsa de copal con la fecha 5 Ajaw. En el lado derecho de su cuerpo, talladas en bajorrelieve, se distinguen firmas de artistas que nombran a los escultores Chan Ch'ok Wahyib' Xook, Ho'chante' Chaahk y Ju'n Nat Omootz. Este último ostenta los títulos ajb'ik'iily ajuxul, "el maestro", 39 "el tallista, el escultor", los cuales, junto con el de pol, "cortador de piedras", señalan que entre los escultores hubo conciencia de clase, así como una formación técnica.

Diez años después, en el año 795, los escultores del Gobernante 7 (algunos de ellos también tallistas del mandatario anterior, Ha'k'in Xook) crearon una de las estelas más bellas conservadas del área maya en general, y que es una de las reliquias del Museo de Arqueología y Etnología de Guatemala: la Estela I2 (fig. 9). Tallada por los cuatro lados, sólo el frente presenta la imagen de varios personajes, mientras que la espalda y los lados muestran largos textos jeroglíficos que relatan, entre otras cosas, una guerra contra el señorío de Pomoná. En la parte superior de la escena, en un lugar claramente privilegiado que denota su protagonismo, se encuentra el Gobernante 7 en una posición sorprendentemente relajada, pues está sentado en un trono con la pierna izquierda flexionada y la derecha colgando del trono. Se inclina hacia abajo para mirar a sus dos jefes militares (colocados en los dos extremos de la estela) y a varios cautivos atados. Los pequeños textos jeroglíficos son etiquetas que identifican a los guerreros del Gobernante 7, a los cautivos y a los escultores de la estela. Son ocho las firmas de los artistas, las cuales mencionan a los escultores Ju'n Nat Omootz, Waajnal Chaak, K'ihn Lakam Chaahk, Ch'ok Ik'iji?, Yajaw Kalo'mte' y a otros tres tallistas, dos de los cuales ostentan el título pol, "cortador de piedras". Los escultores Ju’n Nat Omootz, Waajnal Chaak, K'ihn Lakam Chaahk agregaron a sus firmas el título ajb'ik'iil, "el maestro", señalando, probablemente, que ellos fueron los tallistas y creadores principales de la Estela I2.

Muchas décadas después de la Estela I2 de Piedras Negras, en la segunda mitad del siglo IX, se encontró el último monumento público conocido de la región del río Usumacinta. Esta escultura, denominada Estela Randell y perteneciente a una colección privada, se erigió en el año 864 y es una pieza bastante pequeña que muestra un estilo claramente tardío, tanto en la caligrafía 
de los jeroglíficos como en el canon de representación del personaje andante. ${ }^{40}$ Éste, colocado totalmente de perfil; sostiene en la mano derecha una lanza y en la izquierda un objeto rectangular que semeja una cesta o un códice. El personaje está enmarcado por un texto jeroglífico bastante extenso (singular por ser atípico en esa época tan tardía) con una fecha en cuenta larga, la dedicación y conmemoración del tallado de la estela, así como otros datos personales y políticos de un militar que ostentó el título de sajal. Dentro del marco iconográfico de la escultura se encuentran dos inscripciones jeroglíficas talladas en altorrelieve (a ambos lados del personaje) que forman la firma del artista: Uchante' Yajaw Ojaw Ch'ok.

\section{La creación de monumentos excepcionales}

Como se observa en las esculturas analizadas, los monumentos públicos mayas muestran, en su gran mayoría, la figura estilizada y estandarizada de la máxima autoridad de los señoríos, el gobernante, colocados en las plazas y en los recintos de los templos. ${ }^{4 \mathrm{I}}$ Estas esculturas enfatizan el rango social y político del personaje representado mediante símbolos o atributos propios de su estatus. Reflejan la imagen oficial del gobernante y la realeza (parientes cercanos de éste) por medio de un ideal, de un modelo idealizado del poder político y religioso ostentado por ellos. Es por esta razón que los monumentos contienen, en su gran mayoría, imágenes de tipo nominativo: un personaje de pie con elementos que conforman la escena, muy comúnmente prisioneros, pero también jefes políticos y militares, reinas consortes, herederos, enanos y aves.

Los mayas utilizaron una amplia gama de técnicas escultóricas, como la incisión, el tallado en alto y bajorrelieve, el bulto redondo y el modelado. Para el periodo Clásico Temprano (292-600) se encuentran arreglos simples en las esculturas en piedra, con figuras rígidas e inexpresivas de pie en posición lateral, con los pies sobrepuestos o uno detrás de otro, donde el escultor evitó las formas tridimensionales y evidenció, desde épocas tempranas, una marcada preferencia por la técnica del relieve. ${ }^{42}$

40. Miller y Martin, Courtly Art of the Ancient Maya, I9I.

4I. María Elena Vega Villalobos, “Templos, palacios y tronos: las ciudades”, en Los mayas: voces de piedra, eds. Alejandra Martínez de Velasco Cortina y María Elena Vega Villalobos (México: Ámbar Diseño, 20II), 337-35I.

42. Tatiana Proskouriakoff, A Study of Classic Maya Sculpture (Washington: Carnegie 


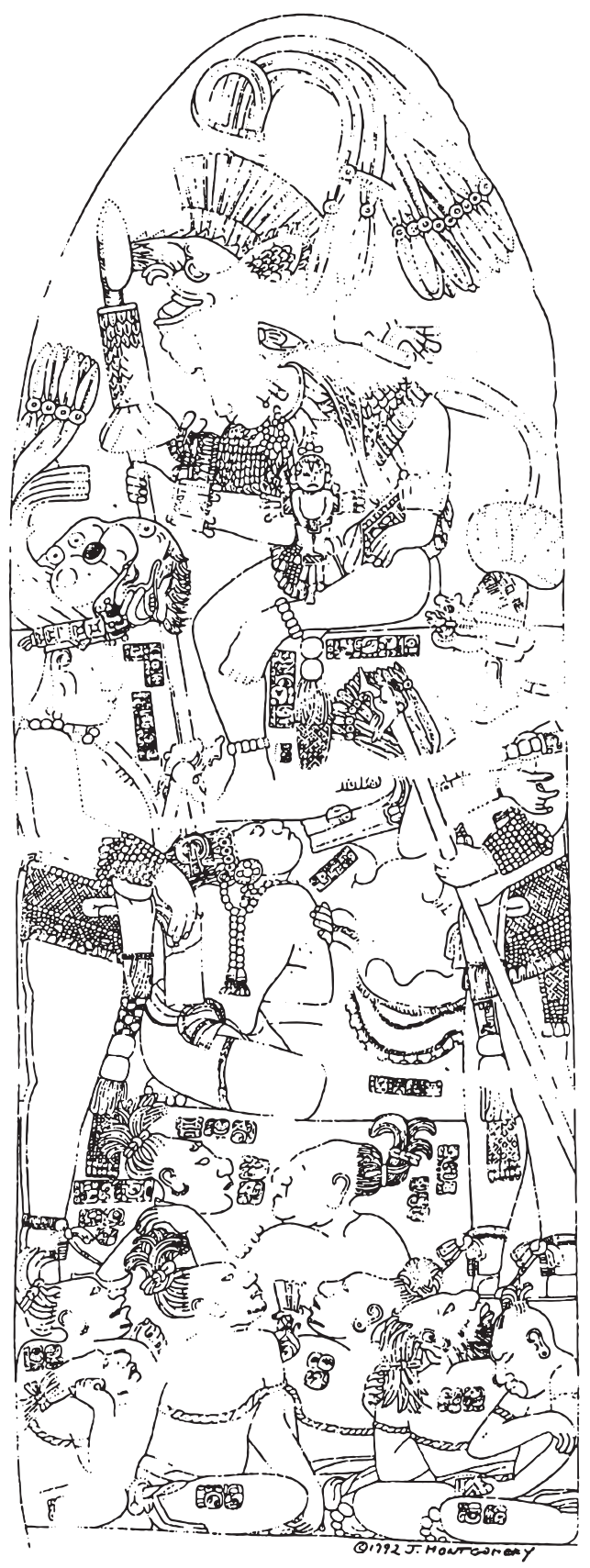

9a) Frente de la Estela I2 de Piedras Negras. Tomada de The John Montgomery Drawings Collection. D.R. (c) 2000 John Montgomery. http://research.famsi.org/uploads/ montgomery/hires/jmo5349pnstı2fr.jpg 

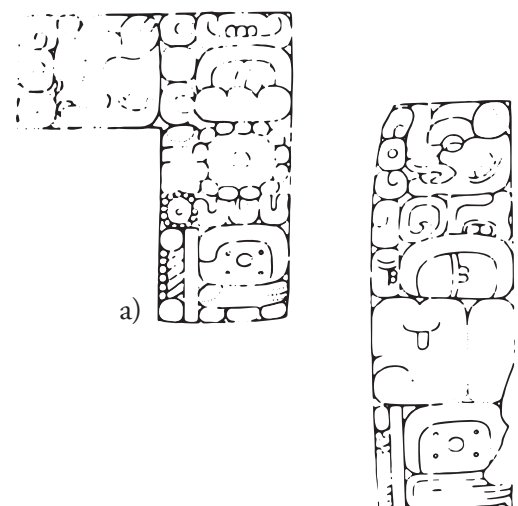

c)

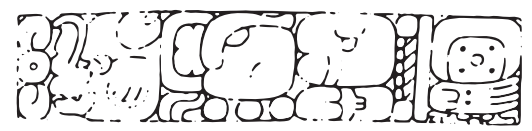

b) 110.0 .0

d)

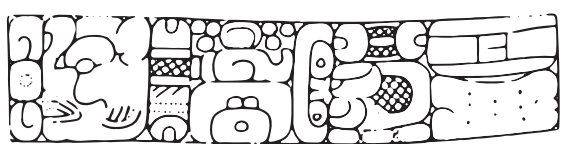

e)

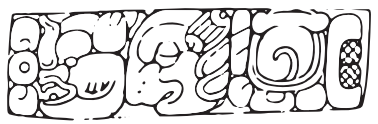

f)

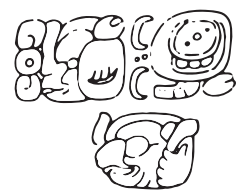

g)

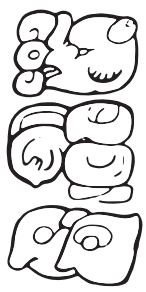

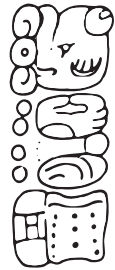

9b) Firmas de los artistas, escultores y tallistas que trabajaron en la confección de la estela: a) I-4= Ju'n Nat Omootz; b) 9-I2= Waajnal Chaak; c) I5-I8= K'ihn Lakam CHaahk; e) 24-26= Ch'ok Ik'ij?; f) 27-29= Yajaw Kalo'mte'; d) 35-38, y g) 42-44, registran el nombre de otros tallistas del monumento que ostentaron el título "cortador de piedras". Tomados de The John Montgomery Drawings Collection. D.R. (C) 2000 John Montgomery, JMo5330-JMo5337.

Como en otros objetos mayas, el arte de los monumentos públicos descansa sobre la línea de contorno. ${ }^{43}$ Fue un arte naturalista, en el que el ser humano podía autorreconocerse, algo que se aprecia sobre todo en las representaciones de la figura humana, lo cual ha hecho pensar a algunos investigadores

Institution, 1950), 2-50; Beatriz de la Fuente, "El arte del retrato entre los mayas", en Artes de México. Reseña del retrato mexicano, núm. I32 (año XVII, 1970): 7-8.

43. George Kubler, Art and Architecture of Ancient America: The Mexican, Maya, and Andean Peoples (Nueva York: Penguin, 1984), 247; Adam Herring, Art and Writing in the Maya Cities, A.D. 600-800. A Poetics of Line (Cambridge University Press, 2005), 260-262. 
que el arte maya buscaba, entre otras cosas, una identidad ontológica entre modelo e imagen, la cual asegurara la pervivencia del gobernante representado en espacios que van más allá del cuerpo. ${ }^{44}$ Por supuesto, en este arte naturalista, se aprendieron y heredaron las diversas estrategias de su confección. ${ }^{45}$

Debido a que el tema de las obras mayas se centraba en el ser humano, es común encontrar descripciones de ellas supeditadas a cuestiones políticas. Así, comúnmente se afirma que el objetivo de los monumentos fue el de impresionar al espectador con el poder del gobernante, su legitimidad, sus conquistas, sus riquezas y sus lujosos atavíos; ${ }^{46}$ su función pudo ser la glorificación de los autócratas, ${ }^{47}$ es decir, el recuento público de las acciones políticas y victorias bélicas del gobernante y la realeza con el único propósito de legitimarse en el poder. Sin embargo, un estudio profundo del tema de las esculturas mayas (principalmente de las estelas) realizado por Stuart, ${ }^{48}$ ha demostrado que las esculturas y su dedicación fueron fundamentales dentro de las ceremonias reales, y que las estelas, más que fungir como glorificación política del gobernante, desempeńaron un papel primordial como participantes activos en el paisaje religioso.

Los monumentos mayas se concibieron fundamentalmente para registrar y conmemorar determinados momentos en el tiempo, mismos que fueron el telón de fondo de la dedicación, el nacimiento, la entronización, la captura de prisioneros, registros de muerte y entierros de diversos personajes. Mediante la notación de eventos que es posible considerar exclusivamente históricos, los escribas y escultores no sólo relataron la gloria del gobernante en turno, tam-

44. Erik Velásquez García, "Los vasos de la entidad política de 'Ik': una aproximación histórico-artística. Estudio sobre las entidades anímicas y el lenguaje gestual y corporal en el arte maya Clásico", tesis de doctorado (México: Universidad Nacional Autónoma de MéxicoFacultad de Filosofía y Letras, 2009), 228-229.

45. Houston e Inomata, The Classic Maya, 257-275.

46. Esther Pasztory, "El arte", en Historia antigua de México. Vol. IV: Aspectos fundamentales de la tradición cultural mesoamericana, coords. Linda Manzanilla Naim y Leonardo López Luján (México: Consejo Nacional para la Cultura y las Artes-Instituto Nacional de Antropología e Historia/Universidad Nacional Autónoma de México-Coordinación de Humanidades-Instituto de Investigaciones Antropológicas/Grupo Editorial Miguel Ángel Porrúa, 200I), 3 I8.

47. De la Fuente, "El arte del retrato entre los mayas", 8.

48. Stuart, "A Study of Maya Inscriptions", I52-176; David S. Stuart, "Kings of Stone: A Consideration of Stelae in Ancient Maya Ritual and Representation", Res. Anthropology and Aesthetics, núms. 29/30 (primavera/otońo, 1996): I48-I7I. 
bién señalaron la interacción de este curso de acontecimientos con el orden cósmico. ${ }^{49}$

El hecho de consagrar monumentos en fechas de final del periodo (momentos trascendentales del calendario maya) muestra que hay una relación directa entre éstos y el calendario: la colocación de piedras se utilizó para marcar el tiempo, es decir, para representar y encarnar el tiempo en sí mismo. Por esta razón es que el rito de atadura de piedra (k'altuun) también se menciona en este complejo ceremonial, pues era complementario a la consagración y se refería a la práctica religiosa de envolver objetos sagrados, esto último quizá con el propósito de proteger y contener la esencia divina presente en la escultura. Estos monumentos, objetos, en la actual concepción, llegaron a adquirir ciertas cualidades sagradas mediante su asociación con finales del periodo, al tiempo que los soberanos resaltaban su prestigio presentándose como los poseedores de los mismos. ${ }^{50}$

Altares, estelas, dinteles y tableros se han recuperado en todos los centros del periodo Clásico. ${ }^{\text {II }}$ En ellos encontramos una repetición mecánica de fórmulas artísticas las cuales señalan que sus creadores se dedicaron a reproducir esquemas idénticos del poder real encarnado en el gobernante, repetidos con infinita monotonía. En mi opinión, sus posturas, gestos y atavíos evidencian que no se quiso representar una imagen individualizada de gobernantes particulares, sino un concepto anclado en prototipos fijos, creados por artistas anteriores durante los primeros siglos de la era cristiana.

A partir del periodo Clásico Tardío, cuando la región de las Tierras Bajas mayas alcanza su momento de mayor esplendor y se producen obras artísticas muy variadas al interior de las numerosas capitales, se encuentran algunos monumentos únicos, que rompen con los cánones artísticos establecidos. Éstos fueron esculturas realizadas por artistas que se negaron a repetir fórmulas convencionales, por lo cual no sorprende que dichos monumentos se hayan firmado en la Antigüedad.

49. Stuart, "A Study of Maya Inscriptions", I59-160; Erik Velásquez García, "Historia de la historia entre los epigrafistas mayistas: desde John Loyd Stephens hasta los tiempos recientes", en IX Coloquio de Análisis Historiográfico. Historiografía de tradición indígena, del II al I3 de octubre de 20I0, ed. Miguel Pastrana Flores (México: Universidad Nacional Autónoma de México-Instituto de Investigaciones Históricas, en prensa).

50. Stuart, "A Study of Maya Inscriptions", I68-170.

5I. La excepción la encontramos en la antigua ciudad de Palenque, Chiapas, donde no se han encontrado hasta la fecha estelas talladas. 
Como he mostrado, a pesar de la existencia de firmas en monumentos públicos, éstas no fueron tan comunes, lo cual señala que la creación artística maya es obra de escultores anónimos sumidos en el mundo del artesanado, cuyas obras no presentan novedades estéticas, pero sí un canon repetitivo de fórmulas. En la gran mayoría de los casos, los monumentos fueron fruto de un sistema ideológico predominantemente religioso, que requirió de artesanos especializados para desarrollar de manera constante este tipo de esculturas de modo mecánico, sin una inquietud creadora. No obstante, las escasas firmas de artistas que hoy conservamos prueban que sí hubo una valoración del artista como tal, el cual perteneció a esferas políticas, sociales y económicas elevadas, y que se diferenció de los tallistas y escultores anónimos, quienes trabajaron para encumbrados maestros y a quienes sólo excepcionalmente se les reconoció en monumentos creados en la época dorada del arte maya prehispánico.

Como se ha visto, las esculturas del señorío de Piedras Negras son excepcionales en cuanto a firmas, debido a que se encuentran varias en un solo monumento. Éstas señalan que los artistas tuvieron conciencia de clase, pues sus títulos denotan no sólo prestigio personal, sino también la formación intelectual y técnica que cada uno de ellos poseía. Las firmas de Piedras Negras evidencian un engranaje colectivo de artistas que incluye pulidores, canteros, tallistas y maestros escultores.

Por otro lado, tampoco es casual que señoríos firmemente establecidos hicieran gala de artistas, tallistas y escultores dedicados de tiempo completo a la creación artística real, pues sólo estas capitales, que evidenciaron una corte estable, podían sostener un estamento importante de escultores cortesanos que trabajaron al servicio real, algunos de ellos incluso para más de un gobernante, como se ve en los monumentos de Piedras Negras.

Las esculturas que he presentado muestran que, a pesar de existir un canon estético bastante estandarizado y repetitivo a lo largo y ancho del territorio maya, se produjeron obras de arte únicas en diferentes momentos del periodo Clásico Tardío. Estas excepciones, a mi parecer, señalan que una idea visual se gestó en la mente del artista, quien no intervino en la confección del texto jeroglífico, sino que sólo pudo plasmar su idea personal de formas en la iconografía.

Para comprender un poco más esta idea se debe revisar un texto jeroglífico creado en el señorío de Palenque. Uno de los pasajes contenidos en la larga inscripción del Tablero de los 96 Bloques Jeroglíficos permite entrever el grado de creatividad que tuvo un escultor maya de la época prehispánica. Casi al 
final del texto jeroglífico — el cual menciona una serie de entronizaciones de diversos gobernantes palencanos—, se descubre escrito lo siguiente: "al esculpir el tablero, [el artista] pintó los jeroglíficos. [El artista] lo concibió como lo había ordenado K'ihnich Janaab' Pakal, señor de cinco k'atuunes". 52

Este pasaje señala que los textos contenidos en los monumentos, enfocados principalmente en temas religiosos, los concebian, ideaban los gobernantes en turno, y no los escultores, quienes, en mi opinión, sí concibieron y crearon visualmente el mensaje político-religioso que el comitente quería transmitir. Las esculturas que he analizado en este artículo, todas excepcionales e innovadoras, todas firmadas, dejan ver que los escultores y tallistas sí tuvieron injerencia en la imagen plasmada en el monumento. Si se acepta que los escultores mayas del Clásico Tardío eran los autores intelectuales y materiales de la imagen contenida en los monumentos, es posible identificarlos como imaginarios o imagineros, un concepto utilizado por Jesús María Parrado del Olmo para los artistas europeos del siglo xvi. Al asimilar a los escultores mayas como los imagineros del siglo Xvi europeo, señalo que ellos fueron verdaderos autores de imágenes. Parafraseando a Parrado del Olmo puedo decir que los artistas mayas, en los casos que he presentado en este ensayo, fueron los inventores de las imágenes "no sólo en un sentido de creador[es] de temas religiosos, sino también en el origen etimológico de imagen como representación visual de un concepto". 53 is

52. Traducción de Albert Davletshin, comunicación personal, 2014.

53. Jesús María Parrado del Olmo, Talleres y escultores del siglo XVI en Castilla y León. Arte como idea. Arte como empresa comercial (Universidad de Valladolid, 2002), 24. 